\title{
Teacher's Directive Expressions Analysis in English Teaching Classes
}

\author{
Haryanto, \\ Husni Mubarok \\ Universitas Islam Nahdlatul Ulama, Jepara \\ hary74pangestu@yahoo.co.id \\ husni@unisnu.ac.id \\ Article History: Submitted 6 September 2017; Accepted 28 February 2018; Published 30 March 2018
}

\begin{abstract}
This paper aimed at finding out the types of teacher's directive expressions at two schools and describing the realizations of directive expressions in English teaching. This research was designed as a qualitative and comparative study. The subjects of the research were English teachers at one Senior High School (first School) at Semarang city and one (second school) at Jepara city. The data of this research were gained through recording, observation and interview. The result showed that there were 11 illocutionary kinds found in the teacher's directive expressions at the first school, and 8 illocutionary types in teacher's directive expressions at the second school. The most illocutionary kind found in the conversation of teaching activity in both schools was question. The directive's expression in both schools used direct and indirect utterances. The teachers of first school more often used language instruction in the classroom because they applied varieties of directive expression. Meanwhile, the teachers at the first school used little directive expressions in English teaching because they did not apply varieties of directive's expressions. The implication in teaching learning English process is that teacher-centered and student-centered type of learning depends on the frequency of production of directive expressions. More directives the teacher expresses, more center the learning by the teacher. On the other hand, less directives the teacher expresses, less center the learning by the teacher.
\end{abstract}

Keywords: directive speech acts, English teaching, comparative descriptive.

\begin{abstract}
ABSTRAK
Penelitian ini bertujuan untuk menemukan tipe ungkapan perintah guru dalam pembelajaran Bahasa Inggris pada dua sekolah yang berbeda dan menggambarkan realisasi dari ungkapan perintah guru dalam pembelajaran Bahasa Inggris. Penelitian ini dirancang sebagai penelitian kualitatif komparatif. Subjek. peneltian ini adalah guru-
\end{abstract}


guru bahasa Inggris pada satu Sekolah Menengah Atas di kota Semarang dan guruguru bahasa Inggris pada satu Sekolah Menengah Atas di kota Jepoara. Data penelitian ini diambil melalui perekaman, pengamatan, dan wawancara. Hasil penelitian menunjukkan babwa terdapat 11 jenis illocutionary dalam ungkapan perintah guru di sekolah pertama dan 8 jenis illocutionary dalam ungkapan perintah guru di sekolah kedua. Tipe illocutionary yang paling banyak ditemukan dalam percakapan kegiatan pembelejaran Bahasa Inggris di kedua sekolah adalah ungkapan bertanya. Ungkapan perintah di kedua sekolah juga menggunakan ujaran langsung dan tidak langsung. Guru-guru bahasa Inggris di sekolah pertama lebih sering menggunaan ungkapan perintah di kelas karena mereka menerapkan macam-macam ungkapan perintah. Sedangkan guru-guru bahasa Inggris di sekolah kedua hanya menggunakan sedikit ungkapan perintah dalam pembelajaran Bahasa Inggris karena mereka kurang menerapkan variasi ungkapan perintah. Hal ini menunjukean babwa pembelajaran berpusat pada guru dan pembelajaran berpusat pada siswa siswa tergantung pada frekuensi pemakaian ungkapan perintah. Semakin banyak guru menggunakan ungkapan perintah, maka pembelajaran semakin berpusat pada guru. Sebaliknya semakin sedikit ungkapan perintab digunakan, maka pembelajaran semakin berpusat pada siswa.

Kata kunci: tindak tutur perintah, pembelajaran bahasa Inggris, pemerian, perbandingan

\section{INTRODUCTION}

Language, as a tool of communication, becomes an important role in transferring information among people. Al-Omari (2013: 20) states that there is a shift from language as an abstract code, i.e., a system of linguistic signs, to language as a process of communication. While English language is widely used throughout the world both as a medium for written and oral communications (Lo, Lajuni, \& Yee, 2007: 14).

Being the one playing central managerial role in classroom, normally the teacher has the authority to direct the students' classroom activities. The teacher's authority is primarily manifested in the teacher's use of directive expressions. As the class has to do activities of varying types and complexities, it is assumed that the teacher uses directive expressions implying various linguistic forms and illocutionary forces including asking, ordering, requesting, inviting, suggesting and permitting.

Directive speech acts are regarded as one function of communication (Yule, 1996: 54). People use directive speech acts to direct someone to something. Directives are speech act that is frequently used in a classroom interaction. The teachers use it to make the students do 
something. The types of directive speech act used are command, order, advice, request, warning, and so forth (Searle, 1969).

Yule (1996: 23) defines directive speech acts as those kinds of speech acts that speakers use to get someone else to do something. They express what the speaker wants. They are commands, orders, requests, and suggestions. They can be formed as positive and or negative sentences. In using a directive, the speaker attempts to make the world fit the word (via the hearer).

Yule (1996: 23) also explained that based on its structure, the sentence/utterance showing speech acts can be classified into three different forms, namely: (i) declarative, (ii) imperative, and (iii) interrogative. Recognizing the relationship between the structural form (declarative, imperatives, and interrogative) and the general communicative functions (statement, question, command/request), Yule distinguished two kinds of speech acts: (i) direct speech acts and, (ii) indirect speech acts. below.

In the terms of utterances form, please attend to these examples

$$
\begin{array}{ll}
\text { You wear a seat belt } & \text { (declarative) } \\
\text { Do you wear a seat belt? } & \text { (Interrogative) } \\
\text { Wear a seat belt! } & \text { (Imperative) }
\end{array}
$$

According to those examples, there are three uses of those forms: (i) declarative form used to make a statement, (ii) interrogative form used to make a question, (iii) imperative one used to make command/request). When there is a direct relationship between the form and the function of utterances, it is called direct speech act. When there is indirect relationship between the form and the function of utterances, it is called indirect speech acts. When a declarative form and interrogative form are used to make request/ command, it is called indirect speech acts. Besides, when an imperative one used to make command/request, it called direct speech acts.

Vanderveken (1990: 189) proposes illocutionary forces in the case of directive speech acts types through performative verbs. Directive speech act means that the speech hearer objects to do what the speaker want as illocutionary force. He also identifies fifty two types of directives speech acts. Vandervaken's classification of directives speech acts falls into the following sub-verbs:1) Directs, 2) Request, 3) Question, inquiry, and interrogate, 4) Urge, encourage, and discourage, 5) Solicit, appeal, petition, 6) Invite, convene, convoke. 7) Beg, supplicate, beseech, implore, entreat, 
conjure, pray, 8) Insist, 9) Tell, instruct, 10) Demand, require, claim, 11) Order, command, dictate, 12) Prescribe, enjoin, 13) Adjure, exercise, 14) Forbidding, 15) Commission, charge, 16) Suggest, propose, 17) Warn, advise, caution, alert, alarm, 18) Recommend, 19) Permit, allow, 20) Authorize, consent, and 21) Invoke, imprecate, intercede.

Indicating the illocutionary forces, Yule (1996: 25) proposes the most significant devices namely IFIDs (Illocutionary Force Indicating Devices). There are five devices to indicate: (i) explicit performative verbs, (ii) implicit performatives verbs, (iii) word order, (iv) intonation, (v) stress, as the following examples:

(1) I order you that you finish your assignment.

(2) You finish your assignment.

(3) Honestly, he is a good man.

(4) Can I meet your father (/)

(5) I tell you that there is no one here

Expression (1) indicates the basic format for explicit perfromative verb as follows:

I hereby $\mathrm{Vp}$ you that you finish your assignment (Based on this IFID, it is called performative verb. The speaker orders someone to finish the assignment).

In expression (2), the speaker implicitly expresses the meaning which is shown below:

I hereby tell you that you finish your assignment. (Based on this IFID, the speaker may tell the hearer to finish the assignment).

In expression (3) the speaker tells the hearer that he is a good man. (Based on IFID, the speaker uses the word order to order the speaker that he/she is a good man.

In expression (4), the speaker is asking the hearer a question - can he/she meet hearer's father? (Based on IFID, the speaker may ask the hearer that he/she call his/her father). 
In expression (5), the speaker is asking the hearer that there is no one there. (Based on IFID, the speaker may tell the hearer that there is nobody around by using stress device).

Identifying the illocutionary points of teachers 'directives expressions, the researcher used not only illocutionary force indicating devices by Yule (1996) but also the theory of felicity conditions by Searle (1969). According to him, there are some circumstances of felicity conditions: (i) propositional content, (ii) preparatory condition, (iii) sincerity condition, and (iv) essential rule, (Searle, 1969: 64). Preparatory condition circumstance happen if hearer would prefer speaker's doing action to their not doing action. The other circumstance, propositional condition, in expressing that proposition expressed, speaker predicates a future act action of speaker. The third is sincerity condition. In terms of directive, it is described as the speaker wants hearer to do asserted actions. The last is essential rule. Searle regarded it as counts as attempt to get hearer to do action.

Looking up some research dealling with directive speech acts that have already been done by the researchers, the researcher found some as follows: First, a research conducted by Sari (2013) who investigated some directive sentences frequently used in teaching non formal institution like Pondok Pesantren. The expressions analysis is in two mixed languages; they are Indonesian and Javanese language.

Another study was conducted by Novianti (2008) which focuses on Melayu language on Sambas Dialect used in that society. The target language to be researched and analyzed is not in English language. It deals with local language study. The fourth study was conducted by Hasan (2013) who discusses sociolinguistic aspects of particular language usage (English) in general.

The next previous study is conducted by Maftuchah (2010). The result obtained are the form of politeness in a directive speech recalled the events within the State Senior High School 1 Surakarta can be viewed on the basis of markers and rules of polite language, the principle of decency directive speech forms employed by students and teachers in the events recalled in surrounding of Surakarta Senior High School 1 Surakarta, the rank order or decency of speech perception directive on Senior high school students 1 Surakarta from the most polite form to the least polite, factors that determine the propriety and form of speech not directive on the events recalled in Surakarta Senior High School 1, among other linguistic factors and non language. 
The other previous study is written by Tamara (2016) which shows that there are several data categorized as commanding acts, request acts, admonishing act, suggesting acts, urging acts, reminding acts, reproving acts. There is no data that categorized as ordering, advising, warning, prohibition, and inviting. Second, the finding researches of female utterances show that almost female express direct utterance in the dialog using commanding in every situation.

The next one is written by Siska (2016) which aimed to find out whether any congruency or in congruency between linguistic form and pragmatic realization both of teacher's and students' illocutionary acts in English classroom interaction, to delineate cooperative principle implied in illocutionary acts of teacher and students, and to delineate politeness implied in illocutionary acts of teacher and students.

The last previous study is written by Saner (2008) which shows the possibility of using Theatre of Absurd as works of literature in the teaching of Speech Act Theory and the applicability of the theory to the analysis of literary works.

Those previous studies have similarity and dissimilarity in this research. The similarity of this current study is it investigates the same topic about directive speech act, therefore it can support this study in term of the theory. Besides, the previous studies and this current study have differences. The first and second studies are conducted on directive speech acts in nonEnglish expressions, even though the third one analyses the English as the targeted language. It necessarily discusses and focuses on types of English directive expressions in classroom interaction of English teaching classes.

To get to be different from other research, this research also describes various types of directives speech acts. Vanderveken (1990) in 'Meaning and Speech Acts' proposes illocutionary forces in the case of the types of directive speech acts through performative verbs. Vandervaken's classification of directives speech acts falls into the following sub-verbs:1) Directs, 2) Request, 3) Question, inquiry, and interrogate, 4) Urge, encourage, and discourage, 5) Solicit, appeal, petition, 6) Invite, convene, convoke. 7) Beg, supplicate, beseech, implore, entreat, conjure, pray, 8) Insist, 9) Tell, instruct, 10) Demand, require, claim, 11) Order, command, dictate, 12) Prescribe, enjoin, 13) Adjure, exercise, 14) Forbidding, 15) Commission, charge, 16) Suggest, propose, 17) Warn, advise, caution, alert, alarm, 18) Recommend, 19) Permit, allow, 20) Authorize, consent, and 21) Invoke, imprecate, intercede. 
Designing this research in comparative one by comparing the English teachers of a city school with another one in countryside, the researcher aims at exploring the factors of education, experience, and culture connected to institutional culture as well as the cultural and social background of teacher and the students. Also, all the previous studies only conducted in a teaching learning class, meanwhile this current study is done in two different classes.

\section{METHOD}

The design of this research was descriptive qualitative comparative study. Descriptive comparative design can be defined as a research that compares two or more variables (Sukmadinata, 2006: 79). This design was selected because the purposes of this study were to describe and to compare the teacher's directive expression in the conversation of English teaching in Karangturi National High School and Mathalibul Huda School. This comparative study used in this research because the data were taken in two different schools but it has a same characteristic. The teaching learning process in both schools used bilingual as a daily language. Therefore, the researcher took these both of schools because of the same characteristic.

The data were the students' and teacher's conversations of English teaching at Karangturi National High School (first school) and at Mathalibul Huda School (second school). The data were taken from the transcription of conversations. The subjects of the research are teachers in both schools. The data of this research were gained through recording, observation and interview. Recording is used by the researcher for record all the activities in the English teaching in both schools. The observation is an effective means of learning to observe how the types of teacher's directive expression, and how is the realization of teacher's directive expression. In this case, the researchers also used interview to the teachers and the students. It was used to gain deep information of the type and the realization of directive's expression in both schools.

The researchers used four steps in analyzing data. The first step is collecting the primary and the secondary data. The primary data were taken from audio recording while the secondary data were taken from interviews. The second step is choosing the utterances which indicate directive expressions purposively. The third step is analyzing the data according to the theories. The last step is presenting the result of analysis in description and comparison. 


\section{FINDINGS AND DISCUSSION}

As stated in underlying theory above, Vanderveken (1990) proposes illocutionary forces in the case of the types of directive speech acts through performative verbs. Corpus data of this research are analysed based on Vandervaken's classification of directives speech acts which consist of some sub-verbs

Within the conversation of teaching activity, the researcher found 8 illocutionary kinds at Karangturi National School, while at Mathalibul Huda School, the researcher found 11 illocutionary kinds. All the illocutionary kinds can be seen in table 1 .

Table 1:

Percentage of Occurance of Directive Speech Acts at Karangturi School and Mathalibul Huda School

\begin{tabular}{|l|l|c|c|c|c|}
\hline \multirow{2}{*}{ No. } & \multicolumn{1}{|c|}{$\begin{array}{c}\text { Directives } \\
\text { Speech Act }\end{array}$} & \multicolumn{2}{|c|}{$\begin{array}{c}\text { At Karangturi } \\
\text { National School }\end{array}$} & \multicolumn{2}{c|}{$\begin{array}{c}\text { At ISH Mathalibul } \\
\text { Huda }\end{array}$} \\
\cline { 3 - 6 } & & Total & Percentage & Total & Percentage \\
\hline 1 & Directs & 12 & $71 \%$ & 5 & $29 \%$ \\
\hline 2 & Request & 20 & $96 \%$ & 1 & $4 \%$ \\
\hline 3 & $\begin{array}{l}\text { Question, inquiry } \\
\text { and interrogate }\end{array}$ & 215 & $44 \%$ & 282 & $56 \%$ \\
\hline 4 & $\begin{array}{l}\text { Urge, encourage, } \\
\text { and discourage }\end{array}$ & 0 & $0 \%$ & 2 & $100 \%$ \\
\hline 5 & Tell, instruct & 23 & $74 \%$ & 8 & $26 \%$ \\
\hline 6 & $\begin{array}{l}\text { Demand, require, } \\
\text { claim }\end{array}$ & 0 & $0 \%$ & 1 & $100 \%$ \\
\hline 7 & $\begin{array}{l}\text { Order, command, } \\
\text { dictate }\end{array}$ & 74 & $63 \%$ & 43 & $37 \%$ \\
\hline 8 & Adjure, exercise & 0 & $0 \%$ & 1 & $100 \%$ \\
\hline 9 & Forbidding & 11 & $79 \%$ & 3 & $21 \%$ \\
\hline 10 & Suggest, propose & 5 & $28 \%$ & 13 & $72 \%$ \\
\hline 11 & $\begin{array}{l}\text { Warn, advise, } \\
\text { caution, alert, alarm }\end{array}$ & 5 & $63 \%$ & 3 & $37 \%$ \\
\hline & Total & $\mathbf{3 7 3}$ utterances & $\mathbf{3 2 5}$ utterances \\
\hline
\end{tabular}

As described on table 1 above, the most illocutionary kind found in the conversation of teaching activity at both schools is question. Question is produced by the teacher to show that the teacher asks for information and need an answer from the students. The occurrence can be seen in the conversation fragment of table 2 . 
Table 2:

Sample Data of Direct Question at Mathalibul Huda School

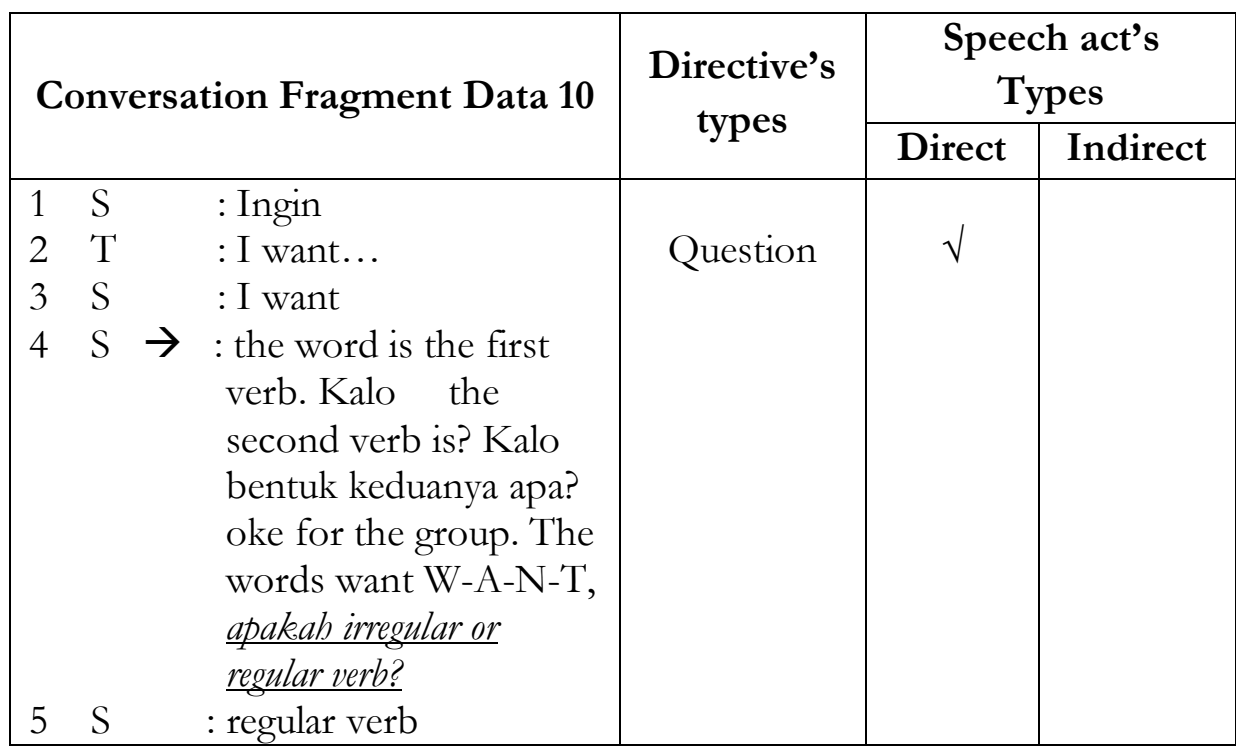

The conversation fragment on table 2 can be analyzed on the following description. The conversation's topic is regular and irregular verb where the conversation took place in the eleventh class of Mathalibul Huda School at 09.00 a.m. The analysis of the speech act is as follows:

T: the word is the first verb. Kalo the second verb is? Kalo bentuk keduanya apa? oke for the group. The words want W-A-N-T, apakah irregular or regular verb?

The italic sentences are formed by interrogative sentence and it is produced by using stressing intonation. These utterances are categorized as directive speech act because the teacher gives question to the students related in the regular and irregular verb topic. In giving question, the teacher gets appropriate response from the students. The appropriate response indicates that there is a good interaction among the teacher and the students. Therefore, the teacher's directive expression successfully delivers the teacher's intention.

Based on the IFID, the researcher interprets that the sentence form is interrogative sentence and the function is directive. It can be concluded that there is direct relationship between the form and the function, because the function of directive expression is to ask for information and it showed by the word apakah as one of WH question. 
Beside IFIDs, it also can be analyzed by the concept of felicity condition. In propositional content circumstance, the students could know and apply regular and irregular verb. In preparatory condition circumstance, the students looked confuse in determining regular and irregular of certain verb. Meanwhile, in other circumstance that is sincerity condition, the teacher wants the students to know and to master regular and irregular verb, and in essential rule circumstance, the teacher orders the students to know and to master regular and irregular verb.

Let us see the other conversation sample of question in table 3.

Table 3:

Sample Data of Indirect Question at Mathalibul Huda School

\begin{tabular}{|c|c|c|c|}
\hline \multirow{2}{*}{$\begin{array}{l}\text { Conversation Fragment Data } \\
10\end{array}$} & \multirow{2}{*}{$\begin{array}{l}\text { Directive's } \\
\text { types }\end{array}$} & \multicolumn{2}{|c|}{$\begin{array}{c}\text { Speech act's } \\
\text { Types }\end{array}$} \\
\hline & & Direct & Indirect \\
\hline $\begin{array}{l}1 \text { S }: \text { Hai Friend, I went// } \\
2 \quad \boldsymbol{T} \rightarrow: \text { I went or I want? } \\
3 \text { S }: \text { I want......... }\end{array}$ & Question & & $\sqrt{ }$ \\
\hline
\end{tabular}

The conversation fragment on table 3 above can be analyzed on the following description. The conversation's topic is Tsunami. The students asked by the teacher for doing presentation in front of the class. This conversation took place in the eleventh class of Mathalibul Huda School at 09.00 a.m. The analysis of the speech act is as follows:

\section{T : I went or I want}

The italic sentences are formed by declarative sentence and are produced by using falling intonation. These utterances are categorized as directive speech act because the teacher gives question to the students related in the pronouncing want or went. In giving question, the teacher also gets appropriate response from the students. It showed by the students' answer which choosing one of the teacher's offering question. The appropriate response indicates that the interaction among the teacher and the students is good. Therefore, the teacher's directive expression successfully delivers the teacher's intention.

Based on the IFID, the researcher interprets that the sentence form is declarative sentence and the function is directive. It can be concluded that there is indirect relationship between the form and the function because the 
form of the utterance is declarative which has function to declare information, in fact this declarative sentence is used to ask information.

Beside IFIDs, it also can be analyzed the speech acts with the concept of felicity condition. In propositional content circumstance, the students could master deeply how to pronounce a word. In preparatory condition circumstance, the students still confused in pronouncing want and went. We go to the next circumstance, sincerity condition, the teacher wants the students to well pronouce the word want and went, then in essential rule, the teacher orders the students to master pronunciation every word especially the words want and went.

Table 4:

Sample Data of Indirect Question at Karangturi National School

\begin{tabular}{|c|c|c|c|}
\hline \multirow[t]{2}{*}{ Conversation Fragment Data 1} & \multirow{2}{*}{$\begin{array}{l}\text { Directive's } \\
\text { types }\end{array}$} & \multicolumn{2}{|c|}{$\begin{array}{c}\text { Speech act's } \\
\text { types }\end{array}$} \\
\hline & & Direct & Indirect \\
\hline $\begin{array}{l}1 \text { T: Very good. I really hope } \\
\text { that you can really get it. So } \\
\text { the next will be this type } \\
\text { everyone. So I told you at the } \\
\text { beginning, the content of the } \\
\text { lesson will be about }(2,0) \text { the } \\
\text { language point we are trying to } \\
\text { develop today is listening, } \\
\text { especially listening to the } \\
\text { specific information. We finish } \\
\text { the first three exercises, and } \\
\text { three forward. And now, we do } \\
\text { to make some connections, } \\
\text { some web that connects to the } \\
\text { exercise two, three, and four. } \\
\text { Hello put your tablet inside the } \\
\text { bag. Well, of course we need to } \\
\text { read the instruction, if you } \\
\text { want to be able to answer the } \\
\text { question. If you don't read the } \\
\text { instruction that means you put } \\
\text { yourself in dangerous situation. } \\
\text { The last person to answer was } \\
\text { Naomi. Naomi, you have } \\
\text { question one to three to be } \\
\text { placed in the correct letter in } \\
\text { A, B, or C. So, which letter }\end{array}$ & Question & & $\sqrt{ }$ \\
\hline
\end{tabular}




\begin{tabular}{|ll|l|l|}
\hline \multicolumn{2}{|c|}{ goes with number one? } & & \\
2 & $\mathrm{~S}: \mathrm{B}, \mathrm{C}, \ldots$ & & \\
$\mathbf{3}$ & $\boldsymbol{T} \rightarrow:$ And the last is ..... & & \\
$4 \mathrm{~S} \quad:$ A & & & \\
\hline
\end{tabular}

The conversation fragment on table 4 can be analyzed on the following description. The conversation's topic is listening exercise. The students are given question for mentioning the last answer. This conversation took place in the eleventh class of Karangturi SHS at 09.00 a.m. The analysis of the speech act is as follows:

\section{$T \quad$ : And the last is}

The italic sentences are formed by declarative sentence and are produced by using falling intonation. These utterances are categorized as directive speech act because the teacher asks for information by giving question to the students for mentioning the last answer. The teacher gives question and gets appropriate response from the students. The appropriate response indicates that there is a direct interaction among the teacher and the students. Therefore, the teacher's directive expression effectively delivers the teacher's intention.

Based on the IFID, the researcher interprets that the sentence form is declarative sentence but the function is directive. It can be concluded that there is indirect relationship between the form and the function because the form of the utterance is declarative which functioned to declare information, in fact this declarative sentence is used to ask information.

Beside IFIDs, the researcher also analyzes the speech acts with the concept of felicity condition. In propositional content, the students could answer all the questions given by the teacher. In preparatory condition, the students do not continue their answer for the question given by the teacher. In sincerity condition, the teacher wants the students to continue and to answer for the question given by the teacher. In essential rule, the teacher orders the students to answer for the question given by the teacher.

As explained above that question as an illocutionary types in both schools have an equal number, there is differentiate between the number of other illocutionary types in Mathalibul Huda School and Karangturi National School. The differences are some illocutionary types like request, order, and forbid in Karangturi National School have higher number than in Mathalibul Huda School. 
Request is produced by the teacher to show that the teacher will ask the students to do something. The occurrence can be seen in the conversation fragment in table 5.

Table 5:

Sample Data of Direct Request at Mathalibul Huda School

\begin{tabular}{|c|c|c|c|}
\hline \multirow[t]{2}{*}{ Conversation Fragment Data 9} & \multirow{2}{*}{$\begin{array}{c}\text { Directive's } \\
\text { types }\end{array}$} & \multicolumn{2}{|c|}{$\begin{array}{c}\text { Speech act's } \\
\text { Types }\end{array}$} \\
\hline & & Direct & Indirect \\
\hline $\begin{array}{l}\text { 1. T : How are you today? } \\
\text { 2. S : Wonderful, excellent, } \\
\text { amazing, and you? } \\
\text { 3. } \mathrm{T} \rightarrow \text { : Very nice, thank you for } \\
\text { asking okay, can you } \\
\text { clean the white board } \\
\text { please? } \\
\text { 4. S : Yes Miss }\end{array}$ & Request & $\sqrt{ }$ & \\
\hline
\end{tabular}

The conversation fragment on table 5 can be analyzed on the following description. The conversation's topic is opening in the beginning lesson. The students requested by the teacher for cleaning the whiteboard. This conversation took place in the eleventh class of Mathalibul Huda School at 09.00 a.m. The analysis of the speech act is as follows:

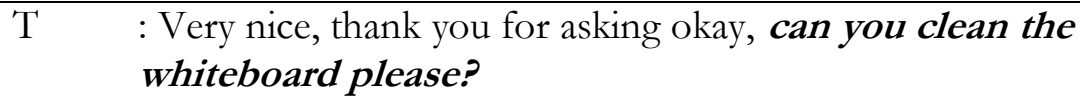

The italic sentences are formed in interrogative sentence and consist of modal verb (can). These utterances are categorized as directive speech act because the teacher requests the students to clean the whiteboard. In request service, the teacher gets appropriate response from the students. It showed by the students answer "yes" in accepting the teacher's request. The appropriate response indicates that the interaction among the teacher and the students is good. Therefore, the teacher's directive expression successfully delivers the teacher's intention.

Based on the IFID, the researcher interprets that the sentence form is interrogative and the function is directive. It can be concluded that there is direct relationship between the form and the function, because the form of the utterance is interrogative which has function to request for service which is showed by the word can . 
Beside IFIDs, it can be analyzed with the concept of felicity condition. The circumstance of propositional content, the students should clean the whiteboard after the end of lesson. In preparatory condition, the students only sit and do not know if the whiteboard is dirty. In sincerity condition, the teacher wants the students to clean the whiteboard every starting the lesson, then in essential rule, the teacher orders the students to clean the whiteboard.

Table 6:

Sample Data of Direct Request at Karangtri National School

\begin{tabular}{|l|l|l|l|}
\hline \multirow{2}{*}{ Conversation Fragment Data 3 } & \multirow{2}{*}{$\begin{array}{c}\text { Directive' } \\
\text { s types }\end{array}$} & \multicolumn{2}{|c|}{$\begin{array}{c}\text { Speech act's } \\
\text { types }\end{array}$} \\
\cline { 3 - 4 } & & Direct & Indirect \\
\hline 1. $\begin{array}{l}\text { T: You want more examples } \\
\text { about sex }\end{array}$ & Request & $\sqrt{ }$ & \\
$\begin{array}{l}\text { education? } \\
\text { 2. } \mathrm{S}: \text { Yes...... }\end{array}$ & & \\
3. T $\rightarrow$ Ok, the same topic, \\
$\begin{array}{l}\text { Orchit. After this I will let you } \\
\text { discuss other topic. Excuse } \\
\text { me, quiet please! }\end{array}$ & & \\
4. TS: (starting the presentation) & & & \\
\hline
\end{tabular}

The above conversation fragment on table 6 can be analyzed in the following description. The conversation's topic is sex education. The students requested by the teacher for silent when their friends do presentation. This conversation took place in the eleventh class of Karangtri NHS at 09.00 a.m. The analysis of the speech act is as follows:

T : Ok, the same topic, Orchit. After this I will let you discuss other
topic. Excuse me, quiet please!

The italic sentences are formed by imperative sentence. These utterances are categorized as directive speech act because the teacher requests the students to keep talking in the classroom. In request something, the teacher gets appropriate response from the students. It showed by the students continue the presentation after the teacher request them to be quiet. The appropriate response indicates that there is a good interaction among the teacher and the students. it showed by the act that all students are silence and continue their presentation. Therefore, the teacher's directive expression successfully delivers the teacher's intention. 
Based on the IFID, the researcher interprets that the sentence form is imperative sentence and the function is directive. It can be concluded that there is direct relationship between the form and the function because the form of the utterance is imperative sentence which has function to ask for service or good and the function of this directive also for asking service or good.

Beside IFIDs, analyze the speech acts with the concept of felicity condition below. In propositional content, the students may not speak when their friend do presentation. In preparatory condition, the class is crowded when a group of students are doing presentation. In sincerity condition, the teacher wants the students to be quiet when a group does presentation. In esential rule, the teacher orders the students to be quiet in the classroom.

The other dissimilarity is the number of illocutionary types in the form of order or command in Karangturi National School is higher than in Mathalibul Huda School. Order is produced by the teacher to show that the teacher wants to command or to order the students to do something. The occurrence can be seen in the conversation fragment in table 7 .

Table 7:

Sample Data of Indirect Order at Mathalibul Huda School

\begin{tabular}{|c|c|c|c|}
\hline \multirow[t]{2}{*}{ Conversation Fragment Data 11} & \multirow{2}{*}{$\begin{array}{c}\text { Directive' } \\
\text { s types }\end{array}$} & \multicolumn{2}{|c|}{$\begin{array}{c}\text { Speech act's } \\
\text { Types }\end{array}$} \\
\hline & & Direct & Indirect \\
\hline $\begin{array}{rrl}1 \mathrm{~S}: & \text { The highest tsunami is } 500 \\
& \text { miles per hour } \\
2 \mathrm{~T} \rightarrow & : \text { You don't need of. The } \\
& \text { highest speed of tsunami } \\
& \text { then don't add } \\
& \text { of after tsunami. Jangan } \\
& \text { tambahkan of lagi setelah } \\
& \text { tsunami ya. } \\
& \text { The highest speed of } \\
& \text { tsunami is }(0,0) \text { your } \\
& \text { answer. } \text { Oke repeat.... } \\
3 \mathrm{~S}: & \text { the highest speed of } \\
& \text { tsunami is................... }\end{array}$ & Order & & $\sqrt{ }$ \\
\hline
\end{tabular}

On table 7 above the conversation fragment can be analyzed on the following description. The conversation's topic is tsunami The teacher orders 
the students for repeating the explanation of the related topic. This conversation took place in the eleventh class of Mathalibul Huda School at 09.00 a.m. The analysis of the speech act is as follows:

\section{T : You don't need of. The highest speed of tsunami then don't add of after tsunami . jangan tambahkan of lagi setelah tsunami ya. The highest speed of tsunami is....your answer. Oke repeat....}

The italic sentences are formed by declarative sentence and produced by falling intonation. These utterances are categorized as directive speech act because the teacher orders the student for repeating her/his explanation. In ordering, the teacher also gets appropriate response from the students. It showed by the students repeat what the teacher wants. The appropriate response indicates that there is a good interaction among the teacher and the students. Therefore, the teacher's directive expression successfully delivers the teacher's intention.

Based on the IFID, the researcher interprets that the sentence form is imperative sentence but the function is directive. It can be concluded that there is indirect relationship between the form and the function because the form of the utterance is imperative which has function to ask for service or good.

Beside IFIDs, it will be analyzed by the concept of felicity condition, in propositional content, the students should master the sentence structure. While, in preparatory condition, the students do mistake in arranging the sentence structure. In sincerity condition: the teacher wants the students to correct her/his explanation. Also, in essential rule, the teacher orders the students to correct her/his explanation.

Table 8:

Sample Data of Indirect Order at Karangturi National School

\begin{tabular}{|c|c|c|c|}
\hline \multirow[t]{2}{*}{ Conversation Fragment Data 4} & \multirow{2}{*}{$\begin{array}{l}\text { Directive's } \\
\text { types }\end{array}$} & \multicolumn{2}{|c|}{$\begin{array}{c}\text { Speech act's } \\
\text { types }\end{array}$} \\
\hline & & Direct & Indirect \\
\hline $\begin{array}{rr}1 & \text { T : Ok. Next! If you don't } \\
& \text { want I will cross you out } \\
& \text { and no score for you. } \\
2 & \text { S : I don't have any pet } \\
& \text { because I don't like pet. } \\
3 & \text { T : Who want to say again? } \\
& \text { Come on! } \\
4 & \text { S : Pet. Pet is animal. There } \\
& \text { are many kind of pets for }\end{array}$ & Order & & $\sqrt{ }$ \\
\hline
\end{tabular}


example fish, cat, and many more.

5 T $\rightarrow$ : Ok, thank you. Kevin next!Grasela, are you Ok. Pay attention to us. The name that I mentioned before please! Ok, Kenan! $6 \mathrm{~S}:$ (explaining)

The conversation fragment above can be analyzed on the following description. The conversation's topic is pet. The teacher orders one of the students for giving opinion related in the topic. This conversation took place in the eleventh class of Karangturi National School at 09.00 a.m. The analysis of the speech act is as follows:

T: Ok, thank you. Kevin next! Grasela, are you Ok. Pay attention to us. The name that I mentioned before please! Ok, Kenan!

The italic sentences are formed by declarative sentence and produced by falling intonation. These utterances are categorized as directive speech act because the teacher orders the student for giving opinion. In ordering the students, they give appropriate response of the teacher's utterance. The appropriate response indicates that there is a good interaction among the teacher and the students. Therefore, the teacher's directive expression effectively delivers the teacher's intention.

Based on the IFID, the researcher interprets that the sentence form is imperative sentence and the function is directive. It can be conclude that there is indirect relationship between the form and the function because the form of the utterance is imperative which has function to ask for service or good and this directive also used to ask for service or good.

Beside IFIDs, it also can be analyzed with the concept of felicity condition, in propositional content, one of the students should giving her/his opinion about pet. In preparatory condition, the students are waiting for the teacher before the teacher points to give their opinion. In sincerity condition, the teacher wants the students to give opinion one by one. In essential rule, the teacher orders the students to give opinion one by one.

The other illocutionary type is suggest. Suggest is produced by the teacher to show that the teacher give attention and give advises for the students. The occurrence can be seen in the conversation fragment in table 9 below. 
Table 9:

Sample Data of Indirect Suggestion at Mathalibul Huda School

\begin{tabular}{|cc|c|c|c|}
\hline \multirow{2}{*}{ Conversation Fragment Data 10 } & \multirow{2}{*}{$\begin{array}{c}\text { Directive's } \\
\text { types }\end{array}$} & \multicolumn{2}{|c|}{$\begin{array}{c}\text { Speech act's } \\
\text { types }\end{array}$} \\
\cline { 3 - 4 } & & Direct & Indirect \\
\hline 1 & $\mathrm{~T}: \begin{array}{l}\text { Oh permintaan kita sendiri } \\
\text { gitukan? Yah permintaan }\end{array}$ & Suggestion & & \\
3 & $\mathrm{~S}: \begin{array}{l}\text { Dan juga membuat// } \\
\text { T } \rightarrow \quad: \text { Yah if you want } \\
\text { an entrepreneur and start } \\
\text { your own business start } \\
\text { your own schedule also }\end{array}$ & & & \\
& & & & \\
& & & \\
\hline
\end{tabular}

The conversation fragment on table 9 above can be analyzed on the following description. The conversation's topic is entrepreneurship. The teacher gives suggestion to the students for making planning and schedule before starting business. This conversation took place in the eleventh class of Mathalibul Huda School at 09.00 a.m. The analysis of the speech act is as follows:

\section{$T \quad:$ Yah if you want an entrepreneur and start your own business start your own schedule also}

The italic sentences are formed by declarative sentence. These utterances are categorized as directive speech act because the teacher gives suggestion to the student for making planning and schedule before starting business. In giving suggestion, the teacher gets appropriate response from the students. The appropriate response indicates that there is a good interaction among the teacher and the students. Therefore, the teacher's directive expression effectively delivers the teacher's intention.

Based on the IFID, the researcher interprets that the sentence form is imperative sentence but the function is directive. It can be concluded that there is indirect relationship between the form and the function because the form of the utterance is imperative which has function to ask for service or good and this directive is used to give suggest.

Beside IFIDs, the researcher analyze the speech acts with the concept of felicity condition. In propositional content, the students should have a planning and a schedule before starting their business. In preparatory condition, the students do not have any idea for making planning in preparing their business. In sincerity condition, the teacher wants the students to have and to make a Schedule related in their business. In 
essential rule, the teacher orders the students to make a schedule related in their business.

Table 10:

Sample Data of Direct Suggestion at Karangturi National School

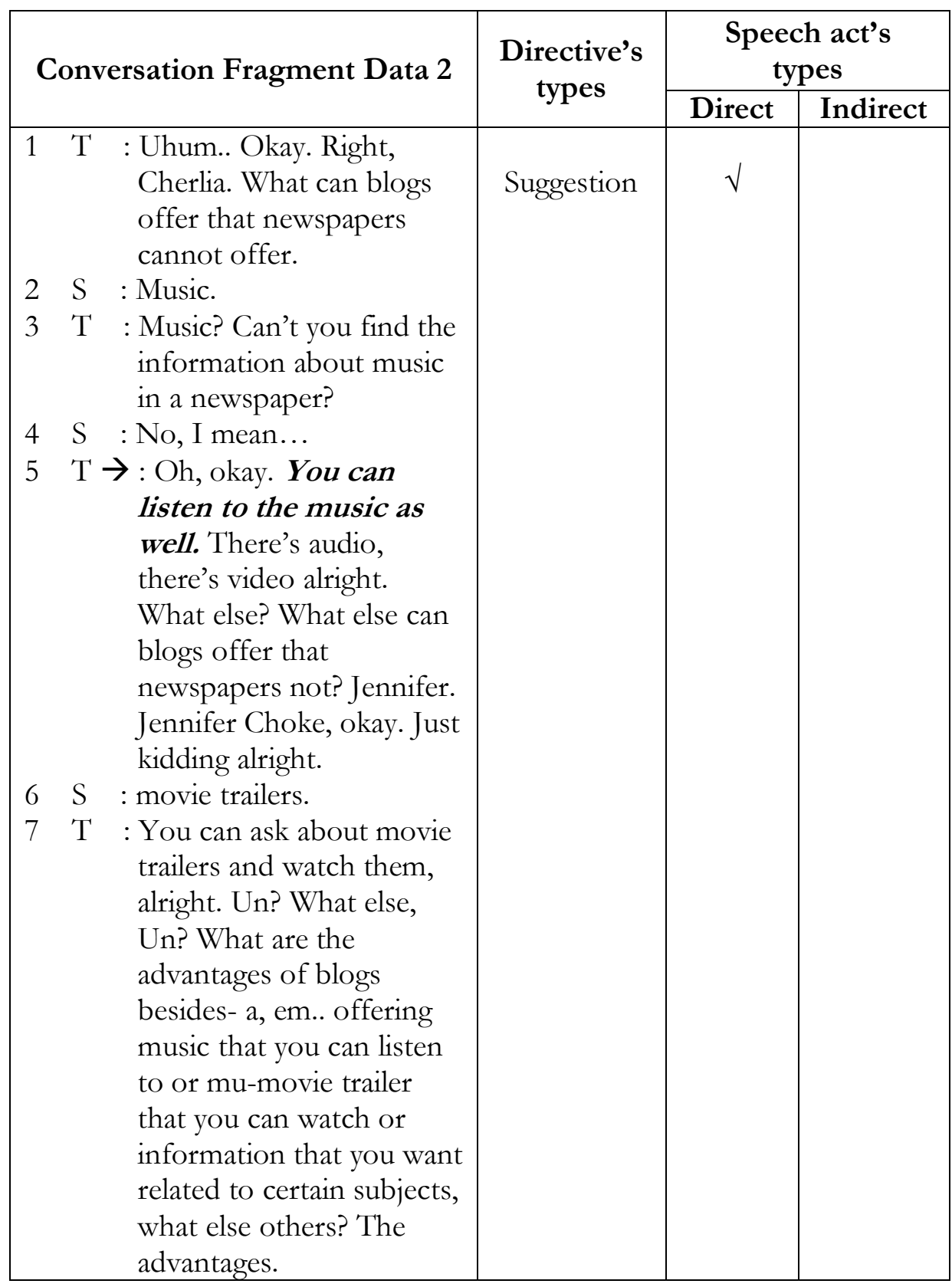

The conversation fragment on table 10 can be analyzed on the following description. The conversation's topic is movie. The teacher gives suggestion to the students for listening music. This conversation took place 
in the eleventh class of Karangturi National School at 09.00 a.m. The analysis of the speech act is as follows:

T: Oh, okay. You can listen to the music as well. There's audio, there's video alright. What else? What else can blogs offer that newspapers not? Jennifer. Jennifer Choke, okay. Just kidding alright.

The italic sentences are formed by declarative sentence. These utterances are categorized as directive speech act because the teacher gives suggestion to the student for listening music. In giving suggestion, the teacher gets appropriate response from the students. It showed by the students' answer that correlates in the teacher's suggestion. The appropriate response indicates that there is a good interaction among the teacher and the students. Therefore, the teacher's directive expression successfully delivers the teacher's intention.

Based on the IFID, the researcher interprets that the sentence form is declarative sentence and the function is directive. It can be concluded that there is direct relationship between the form and the function because the form of the utterance is declarative which has function to declare something, in fact this directive used to give suggestion. Beside IFIDs, it also can be analyzed with the concept of felicity condition. In propositional content, the students should listen the music as one of electric learning. In preparatory condition, the students do not listen the music, therefore they cannot learn more through music. Then in sincerity condition, the teacher wants the students to listen the music. In essential rule, the teacher orders the students to listen the music.

\section{CONCLUSION}

Summarizing the background and data analysis as described above, the researcher at last draw a conclusion that types of directive's speech act at Karangturi National High School is different from those at Mathalibul Huda Islamic High School. There are 8 illocutionary types of directive's speech acts found in English teaching of Karangturi SHS and 11 illocutionary types of directive's speech acts found in English teaching of Mathalibul Huda School.

The most illocutionary types found in the conversation of teaching activity in both schools is question. Both also use directive's expressions in direct and indirect types. The teachers of Karangturi National High School more often used language instruction in the classroom because they apply a varieties directive expression. Meanwhile, the teacher at Mathalibul Huda School only uses several directive expressions in English teaching because 
they do not apply a variety of directive's expression.

In conclusion, the English teaching activities at Karangturi National School emphasize on the students center learning, while the English teaching activities at Mathalibul Huda School emphasize on the teacher center learning. At last, the implication in teaching learning English process is that teacher-centered and student-centered type of learning depends on the frequency of production of directive expressions. More directives the teacher expresses, more center the learning by the teacher. On the other hand, less directives the teacher expresses, less center the learning by the teacher.

\section{REFERENCES}

Al-Omari, S. K. 2013. Promising as a Speech Act in Jordanian Arabic. International Forum of Teaching and Studies, 9(1), 30-35.

Hasan. 2013. Politeness Strategy of Directive used in Indonesian and Libyan Students of UNDIP when using English as a foreign language. Diponegoro University.

Lo, B., Lajuni, N., \& Yee, C. C. P. 2007. Developing English Communication Skills Through Self-Practice Method. Labuan EJournal of Muamalat and Society, 1(1), 14-20.

Maftuchah, N. 2010. Kesantunan Bentuk. Tuturan Direktif di Lingkungan SMA Negeri 1 Surakarta. Universitas Negeri Surakarta.

Novianti, E. 2008. Kesantunan Direktif pada Bahasa Melayu Dialek Sambas. Diponegoro University.

Saner. 2008. Teaching Speech Act Theory and its Reflection on the Study of The Theatre of Absurd in ELT Classes. Egypt: Dokuz Eylul University.

Sari, K. P. 2013. Islamic Priests' Directive at Pondok Pesantren Al-Muhammad Сери Blora. Diponegoro University.

Searle, J. R. 1969. Speech acts: An Essay in the Philosophy of Language. London: Cambridge University Press.

Siska, V. 2016. Analyzing Illocutionary Acts of Teacher and Students in English Classroom Interaction at Tunas Mekar Indonesia Elementary School. Bandar Lampung University.

Sukmadinata, N. S. 2006. Metode Penelitian Pendidikan. Bandung: Remaja Rosdakarya.

Tamara, C. W. 2016. Directive Speech Act Realization in the Teaching and Learning at Magister of Language Studies Mubammadiyah University of Surakarta. Universitas Muhammadiyah Surakarta.

Vanderveken, D. 1990. Meaning and Speech Acts. Cambridge: Cambridge University Press.

Yule, G. 1996. Pragmatik. Yogyakarta: Pustaka Pelajar. 